\title{
Effect of Post-Harvest Treatments on Enzyme Activity and Quality of Cold Stored Ber Fruit
}

\author{
Sukhjit K.JAWANDHA*, Navjot GUPTA, Jasbir S. RANDHAWA \\ Punjab Agricultural University, Department of Fruit Science, Ludbiana 141004, India; skjawandha@pau.edu (*corresponding author)
}

\begin{abstract}
Ber (Zizyphus mauritiana Lamk) fruits are perishable in nature and have poor shelf- life. To extend the storage life of ber fruits different post-harvest treatments, like $\mathrm{CaCl}_{2}\left(0.5,1.0\right.$ and 2.0\%), $\mathrm{Ca}\left(\mathrm{NO}_{3}\right)_{2}\left(0.5,1.0\right.$ and 2.0\%), gibberellic acid $\left(\mathrm{GA}_{3}\right)(20,40$ and $60 \mathrm{ppm})$ and Bavistin (0.1\%) were given to fruits and their effect was studied on the storage life and quality of 'Umran' ber (Zizyphus mauritiana Lamk) fruits under cold storage conditions. Fruits of uniform size and colour were harvested, from healthy plants, and subjected to post harvest dip of different chemicals, before packing in CFB boxes and placed in cold storage $\left(3-5^{\circ} \mathrm{C}\right.$ and $\left.85-90 \% \mathrm{RH}\right)$ They have been evaluated after 10, 20 and 30 days of storage for physiological loss in weight (PLW), firmness, pectin methyl esterase (PME) activity and palatability rating. The PLW increased and fruit firmness decreased during storage at each treatment. The sensory rating increased up to 10 days at all treatments, except control but subsequently it decreased during storage. The increase rate in PME activity was faster, up to 10 days, in untreated fruits, while treated fruits showed slower rise in PME activity, up to 20 days with a decline afterwards. It can be concluded that ber fruits can be stored up to 20 days by post-harvest treatment using $\mathrm{GA}_{3}$ at $60 \mathrm{ppm}$, with acceptable quality.
\end{abstract}

Keywords: ber (Zizyphus mauritiana Lamk), calcium, GA PME, Ssorage, Umran

\section{Introduction}

Ber fruit is very popular among consumers due to its high nutritive value and comparatively low market price. In Punjab the commercial cultivation of ber is largely focused on one single cultivar, 'Umran'. However, due to its perishable nature and poor shelf-life, high post-harvest losses are major constraints in developing ber fruit industry (Salunkhe and Kadam, 1995). Fruit quality is highly affected during storage due to increased metabolic activity of some enzymes resulting in deterioration of fleshy organs (Looney, 1970). Higher activity of cell wall degrading enzymes results in fruit softening, which subsequently leads to fruit decay. Calcium is important in the maintenance of cell wall integrity in plants. Heavy influx of external or internal calcium inhibits ripening process due to reduction in enzymatic activity. Application of calcium compounds (chloride, nitrate, sulphate and phosphate) reduced decay losses in ber fruits (Gupta et al., 1987). Similarly, certain growth regulators, like gibberellic acid, are known to promote the shelf life of fruits. Mehta et al. (1986) reported that $\mathrm{GA}_{3}$ at $100 \mathrm{ppm}$ significantly suppresses the succinate activities of malate-dehydrogenase during post-harvest ripening of papaya and thus retard ripening. Masalkar and Wavhal (1991) also reported that application of growth regulators affects the physico-chemical properties of ber fruit. Growers of ber fruit can be benefited if storage life is extended. Therefore, the present investigations were conducted to examine the effect of pre-harvest application of various chemicals on fruit quality during storage.

\section{Materials and methods}

The present investigations were carried out at Punjab Agricultural University, Ludhiana on uniform trees of ber fruit cv. 'Umran'. Fruits were harvested at optimum maturity from the selected trees and healthy and uniform fruits, subjected to post-harvest dip of different chemicals viz., $\mathrm{T}_{1}: \mathrm{CaCl}_{2}(0.5 \%), \mathrm{T}_{2}: \mathrm{CaCl}_{2}(1.0 \%), \mathrm{T}_{3}: \mathrm{CaCl}_{2}(2.0 \%), \mathrm{T}_{4}$ : $\mathrm{Ca}\left(\mathrm{NO}_{3}\right)_{2}^{2}(0.5 \%), \mathrm{T}_{5}: \mathrm{Ca}\left(\mathrm{NO}_{3}\right)_{2}(1.0 \%), \mathrm{T}_{6}^{2}: \mathrm{Ca}\left(\mathrm{NO}_{3}\right)_{2}^{4}$ (2.0\%), $\mathrm{T}_{7}: \mathrm{GA}_{3}(20 \mathrm{ppm}), \mathrm{T}_{8}: \mathrm{GA}_{3}(40 \mathrm{ppm}) \mathrm{T}_{9}: \mathrm{GA}_{3}(60$ ppm) $\mathrm{T}_{10}$ : Bavistin (0.1\%) and $\mathrm{T}_{11}$ : Control (untreated) before packaging. One kilogram fruit from each replication of respective treatment was packed in nylon carriers. Thereafter, the packed fruits were placed in corrugated fibre board (CFB) boxes ( $5 \%$ perforations) with paper lining and kept in cold storage $\left(3-5^{\circ} \mathrm{C}, 85-90 \%\right.$ R.H). Fruit samples were analyzed for physico-chemical characteristics after 10, 20 and 30 days of storage. The physiological loss in weight (PLW) was calculated based on initial weight and weight at subsequent intervals and the weight loss calculated. Sensory rating (PR) was recorded on the basis of score card viz: 1 -poor; 2 -fair; 3 -good; 4 -very good and 5 -excellent. Fruit firmness was measured with the help of a 'fruit pressure tester' (FT-444, Italy) in $\mathrm{kg} / \mathrm{cm}^{2}$. The PME activity was determined using the method of Mahadevan and Sridhar (1982). The data were analyzed statistically by completely randomized design (CRD) method (Gomez and Gomez, 1984). 


\section{Results and discussion}

Data presented in Tab. 1 shows a significant increase in physiological loss in weight (PLW) with the increase of storage period. The maximum loss in weight $(2.8 \%)$ was noted in control fruits after 10 days of storage, followed by Bavistin (0.1\%) treatment. The minimum PLW (1.28\%) was recorded in $\mathrm{GA}_{3}-60 \mathrm{ppm}$ treated fruits, followed by $\mathrm{CaCl}_{2}(2 \%)$ treatment. After 20 days of storage, the maximum PLW (4.2\%) was recorded in control fruits, followed by Bavistin (0.1\%) treatment. Whereas, the minimum PLW (2.35\%) was recorded in $\mathrm{GA}_{3}-60 \mathrm{ppm}$ treated fruits, followed by $\mathrm{CaCl}_{2}(2 \%)$ treatment. At the end of storage maximum PLW (6.2\%) was found in control fruits while the minimum was recorded in $\mathrm{GA}_{3}-60 \mathrm{ppm}$ treated fruits, followed by $\mathrm{CaCl}_{2}(2 \%)$ treatment. Results revealed that the minimum PLW was recorded in $\mathrm{GA}_{3}-60 \mathrm{ppm}$ treated fruits. Similar results were also reported by Randhawa $e t$ al. (2002) in plum fruits and Majumdar et al. (1981) in mango. In all the treatments PLW significantly increased with the increase in storage period. This was due to the increase in respiration and transpiration processes during storage.

Fruit firmness decreased with the advancement of storage period (Tab. 2). The maximum fruit firmness $(8.66 \mathrm{~kg} /$ $\mathrm{cm}^{2}$ ) was recorded at $\mathrm{GA}_{3}-60 \mathrm{ppm}$ treated fruits, after 10 days of storage; the minimum fruit firmness $\left(7 \mathrm{~kg} / \mathrm{cm}^{2}\right)$ was noticed in control fruits. Similarly, after 20 and 30 days of storage, the maximum fruit firmness was observed at $\mathrm{GA}_{3}-60 \mathrm{ppm}$ treated fruits, whereas the minimum fruit firmness was found at control fruits. The highest retention of fruit firmness, after $\mathrm{GA}_{3}-60 \mathrm{ppm}$ treatment may appear due anti-senescence properties of gibberellic acid (Lazan et al. 1993). According to Ben et al. (1996) the application of GA to persimmon fruits delays the rate of fruit softening. At all treatments fruit firmness decreased with the increase of storage period, it was also reported by Siddiqui and Gupta (1989) ber fruits. The reduction in fruit

Tab. 1. Effect of different post-harvest treatments on physiological loss in weight (PLW) of ber fruits during cold storage

\begin{tabular}{|c|c|c|c|c|}
\hline \multirow{3}{*}{ Treatment } & \multicolumn{3}{|c|}{ PLW (\%) } & \multirow{3}{*}{ Mean } \\
\hline & \multicolumn{3}{|c|}{ Days after storage } & \\
\hline & 10 & 20 & 30 & \\
\hline $\mathrm{CaCl}_{2} 0.5 \%$ & 1.70 & 3.04 & 4.72 & 3.15 \\
\hline $\mathrm{CaCl}_{2} 1 \%$ & 1.52 & 2.76 & 4.64 & 2.97 \\
\hline $\mathrm{CaCl}_{2} 2 \%$ & 1.36 & 2.40 & 4.45 & 2.73 \\
\hline $\mathrm{Ca}\left(\mathrm{NO}_{3}\right)_{2} 0.5 \%$ & 1.83 & 3.25 & 4.82 & 3.30 \\
\hline $\mathrm{Ca}\left(\mathrm{NO}_{3}\right)_{2} 1 \%$ & 1.72 & 2.94 & 4.70 & 3.12 \\
\hline $\mathrm{Ca}\left(\mathrm{NO}_{3}\right)_{2} 2 \%$ & 1.50 & 2.82 & 4.55 & 2.95 \\
\hline $\mathrm{GA}_{3}-20 \mathrm{ppm}$ & 1.62 & 2.90 & 4.60 & 3.04 \\
\hline $\mathrm{GA}_{3}-40 \mathrm{ppm}$ & 1.40 & 2.63 & 4.50 & 2.84 \\
\hline $\mathrm{GA}_{3}-60 \mathrm{ppm}$ & 1.25 & 2.35 & 4.06 & 2.55 \\
\hline Bavistin $0.1 \%$ & 2.00 & 3.32 & 4.83 & 3.38 \\
\hline Control (untreated) & 2.80 & 4.20 & 6.20 & 4.40 \\
\hline Mean & 1.70 & 2.96 & 4.73 & \\
\hline
\end{tabular}

$\mathrm{CD}(5 \%)$ Treatments $(\mathrm{A})=0.109$, Days after storage $(\mathrm{B})=0.057$, Interaction $(\mathrm{A} \times \mathrm{B})=0.189$

Tab. 2. Effect of different post-harvest treatments on fruit firmness of ber fruits during cold storage

\begin{tabular}{|c|c|c|c|c|}
\hline \multirow{3}{*}{ Treatment } & \multicolumn{3}{|c|}{ Fruit firmness $\left(\mathrm{kg} / \mathrm{cm}^{2}\right)$} & \multirow{3}{*}{ Mean } \\
\hline & \multicolumn{3}{|c|}{ Days after storage } & \\
\hline & 10 & 20 & 30 & \\
\hline $\mathrm{CaCl}_{2} 0.5 \%$ & 8.08 & 6.60 & 5.56 & 6.74 \\
\hline $\mathrm{CaCl}_{2} 1 \%$ & 8.25 & 6.75 & 6.00 & 7.00 \\
\hline $\mathrm{CaCl}_{2} 2 \%$ & 8.48 & 7.25 & 6.33 & 7.35 \\
\hline $\mathrm{Ca}\left(\mathrm{NO}_{3}\right)_{2} 0.5 \%$ & 7.91 & 6.50 & 5.40 & 6.60 \\
\hline $\mathrm{Ca}\left(\mathrm{NO}_{3}\right)_{2} 1 \%$ & 8.25 & 6.67 & 5.75 & 6.89 \\
\hline $\mathrm{Ca}\left(\mathrm{NO}_{3}\right)_{2} 2 \%$ & 8.41 & 6.83 & 6.00 & 7.08 \\
\hline $\mathrm{GA}_{3}-20 \mathrm{ppm}$ & 8.00 & 6.75 & 5.75 & 6.83 \\
\hline $\mathrm{GA}_{3}-40 \mathrm{ppm}$ & 8.50 & 7.00 & 5.90 & 7.13 \\
\hline $\mathrm{GA}_{3}-60 \mathrm{ppm}$ & 8.66 & 7.40 & 6.50 & 7.52 \\
\hline Bavistin $0.1 \%$ & 7.86 & 6.50 & 5.16 & 6.51 \\
\hline Control (untreated) & 7.00 & 5.25 & 4.20 & 5.48 \\
\hline Mean & 8.12 & 6.67 & 5.68 & \\
\hline
\end{tabular}

$\mathrm{CD}(5 \%)$ Treatments $(\mathrm{A})=0.308$, Days after storage $(\mathrm{B})=0.161$, Interaction $(\mathrm{A} \times \mathrm{B})=0.294$ 
88

Tab. 3. Effect of different post-harvest treatments on palatability rating of ber fruits during cold storage

\begin{tabular}{|c|c|c|c|c|}
\hline \multirow{3}{*}{ Treatment } & \multicolumn{3}{|c|}{ Palatability rating } & \multirow{3}{*}{ Mean } \\
\hline & \multicolumn{3}{|c|}{ Days after storage } & \\
\hline & 10 & 20 & 30 & \\
\hline $\mathrm{CaCl}_{2} 0.5 \%$ & 4.40 & 3.15 & 2.40 & 3.32 \\
\hline $\mathrm{CaCl}_{2} 1 \%$ & 4.50 & 3.41 & 2.50 & 3.47 \\
\hline $\mathrm{CaCl}_{2} 2 \%$ & 4.80 & 3.60 & 3.10 & 3.83 \\
\hline $\mathrm{Ca}\left(\mathrm{NO}_{3}\right)_{2} 0.5 \%$ & 4.30 & 3.00 & 2.20 & 3.17 \\
\hline $\mathrm{Ca}\left(\mathrm{NO}_{3}\right)_{2} 1 \%$ & 4.38 & 3.00 & 2.33 & 3.24 \\
\hline $\mathrm{Ca}\left(\mathrm{NO}_{3}\right)_{2} 2 \%$ & 4.58 & 3.50 & 2.75 & 3.61 \\
\hline $\mathrm{GA}_{3}-20 \mathrm{ppm}$ & 4.50 & 3.33 & 2.50 & 3.44 \\
\hline $\mathrm{GA}_{3}-40 \mathrm{ppm}$ & 4.70 & 3.60 & 2.85 & 3.72 \\
\hline $\mathrm{GA}_{3}-60 \mathrm{ppm}$ & 4.83 & 3.75 & 3.25 & 3.94 \\
\hline Bavistin $0.1 \%$ & 4.25 & 3.10 & 2.00 & 3.12 \\
\hline Control (untreated) & 3.83 & 2.60 & 1.62 & 2.68 \\
\hline Mean & 4.46 & 3.28 & 2.50 & \\
\hline
\end{tabular}

$\mathrm{CD}(5 \%)$ Treatments $(\mathrm{A})=0.183$, Days after storage $(\mathrm{B})=0.096$, Interaction $(\mathrm{A} \times \mathrm{B})=0.210$

Tab. 4. Effect of different post-harvest treatments on pectin methyl esterase (PME) activity in ber fruits during cold storage

\begin{tabular}{|c|c|c|c|c|}
\hline \multirow{3}{*}{ Treatment } & \multicolumn{3}{|c|}{ PME activity ( $\mathrm{ml}$ of $0.02 \mathrm{~N} \mathrm{NaOH}$ used) } & \multirow{3}{*}{ Mean } \\
\hline & \multicolumn{3}{|c|}{ Days after storage } & \\
\hline & 10 & 20 & 30 & \\
\hline $\mathrm{CaCl}_{2} 0.5 \%$ & 1.64 & 2.25 & 1.62 & 1.83 \\
\hline $\mathrm{CaCl}_{2} 1 \%$ & 1.40 & 2.20 & 1.65 & 1.75 \\
\hline $\mathrm{CaCl}_{2} 2 \%$ & 1.29 & 2.06 & 1.78 & 1.71 \\
\hline $\mathrm{Ca}\left(\mathrm{NO}_{3}\right)_{2} 0.5 \%$ & 1.68 & 2.30 & 1.56 & 1.85 \\
\hline $\mathrm{Ca}\left(\mathrm{NO}_{3}\right)_{2} 1 \%$ & 1.66 & 2.22 & 1.63 & 1.83 \\
\hline $\mathrm{Ca}\left(\mathrm{NO}_{3}\right)_{2} 2 \%$ & 1.43 & 2.10 & 1.72 & 1.75 \\
\hline $\mathrm{GA}_{3}-20 \mathrm{ppm}$ & 1.67 & 2.20 & 1.66 & 1.84 \\
\hline $\mathrm{GA}_{3}-40 \mathrm{ppm}$ & 1.31 & 2.10 & 1.74 & 1.72 \\
\hline $\mathrm{GA}_{3}-60 \mathrm{ppm}$ & 1.24 & 2.04 & 1.85 & 1.71 \\
\hline Bavistin $0.1 \%$ & 1.72 & 2.28 & 1.54 & 1.84 \\
\hline Control (untreated) & 2.26 & 1.92 & 1.41 & 1.86 \\
\hline Mean & 1.57 & 2.15 & 1.65 & \\
\hline
\end{tabular}

$\mathrm{CD}(5 \%)$ Treatments $(\mathrm{A})=0.042$, Days after storage $(\mathrm{B})=0.066$, Interaction $(\mathrm{A} \times \mathrm{B})=0.022$

firmness with the passage of time was probably due to hydrolytic enzyme activity.

Fruit palatability rating declined during the entire storage period (Tab. 3). After 10 days of storage, the maximum palatability rating (4.83) was recorded in $\mathrm{GA}_{3}-60 \mathrm{ppm}$ treated fruits. The minimum palatability rating (3.83) was observed in control fruits. Similar trend was followed by PR after 20 and 30 days of storage. The maximum palatability rating, after 30 days of storage was maintained by $\mathrm{GA}_{3}-60 \mathrm{ppm}$ treated fruits. Similar results were also reported by Chahal and Bal (2003) in ber fruits after 30 days of cold storage. This could be attributed to the low rates of respiration and transpiration in fruits.

A significant increase and decrease in PME activity was noticed with the progress of storage period in all the treatments (Tab. 4). The maximum PME activity (2.26) was recorded in control fruits after 10 days of storage, where the minimum PME activity (1.24) was found in $\mathrm{GA}_{3}-60 \mathrm{ppm}$ treated fruits. After 20 days of storage, the highest PME activity (2.30) was recorded at $\mathrm{Ca}\left(\mathrm{NO}_{3}\right)_{2}$ (0.5\%). The lowest PME activity (2.04) was observed at $\mathrm{GA}_{3}-60 \mathrm{ppm}$ treated fruits. At the end of storage trend was changed and the maximum PME activity (1.85) was observed at $\mathrm{GA}_{3}-60 \mathrm{ppm}$ treated fruits and minimum PME activity (1.41) was recorded in control fruits. The results indicate that, after 30 days of storage, maximum PME activity was recorded at $\mathrm{GA}_{3}-60 \mathrm{ppm}$ treated fruits, as compared to other treatments. It might be due to the presence of high substrate level for PME activity at later stages in $\mathrm{GA}_{3}-60 \mathrm{ppm}$ treated fruits, which was already decomposed to the higher extent at the early stages of storage in other treatments. But, GA, delayed the senescence and maintained the fruit in good condition up to 30 days of storage. The PME activity was increased up to 20 days of storage, than it was decreased. The decrease in PME activity at later stage of storage was also reported by Mahajan (1994) regarding apple fruits. 


\section{Conclusions}

It may be concluded that ber fruits remained in acceptable condition up to 20 days of cold storage when treated with $\mathrm{GA}_{3} 60 \mathrm{ppm}$ and $\mathrm{CaCl}_{2}$ (2\%) after harvesting. After this period the elevated enzyme activity accelerated degradation/senescence process in fruits and deteriorated their quality.

\section{References}

Ben AR, Saks Y, Sonego L, Frank A (1996). Cell wall metabolism in gibberellin treated persimmon fruits. Plant Growth Regulation 19:25-33.

Chahal S, Bal JS (2003). Effect of post harvest treatments and packaging on shelf life of Umran ber at cool temperature. J Res PAU Ludhiana 40:363-370.

Gomez KA, Gomez AA (1984). Statistical procedures for agricultural research. John Wiley and Sons, New York, 7-129 p.

Gupta OP, Jindal PC, Singh BP (1980). Effect of pre-harvest spray of calcium nitrate on the storage behaviour of grapes cv. 'Perlette.' J Res Haryana Agric Univ 10:204-206.

Lazan H, Alid ZM, Selamat MK (1993). The underline biochemistry of the effect of modified atmosphere and storage temperature on firmness decrease in papaya. Acta Hort 343:169-173.

Looney NE (1970). Metabolic control of ripening. Hort Sci $5: 39-40$
Mahadevan A, Sridhar R (1982). Methods in physiological plant pathology. Sivagami Publ Madras.

Mahajan BVC (1994). Biochemical and enzymatic changes in apple during cold storage. J Food Sci Technol 31:142-144.

Majumdar G, Modi VV, Palejwala VA (1981). Effect of plant growth regulators on mango ripening. Ind J Exp Biol 19:885-886

Masalkar SD, Wavhal KN (1991). Effect of various growth regulators on phsico-chemical properties of ber cv. 'Umran'. Maha J Hort 5:37-40.

Mehta PM, Raj SS, Raju PS (1986). Influence of fruit ripening retardants on succinate and malate dehydrogenase in papaya fruits with emphasis on preservation. Indian J Hort 43:169173.

Randhawa JS, Bal JS, Kaundal GS (2002). Effect of post harvest dip of growth regulators on shelf life of plum at low temperature. Proc Nat Workshop Post Harvest Management Horticultural Produce, Chandigarh, 175-180 p.

Salunkhe DK, Kadam SS (1995). Handbook of fruit science and technology, Marcel Dekker Inc., New York, 387 p.

Siddiqui S, Gupta OP (1989). Effect of pre-harvest spray of calcium on shelf-life of ber (Zizyphus mauritiana Lamk) Fruit Res and Dev Rep 6:172-176. 